\title{
Research Priorities to Improve Future Environmental Water Outcomes
}

\begin{abstract}
Avril C. Horne ${ }^{1 *}$, J. Angus Webb ${ }^{1}$, Erin O'Donnell ${ }^{2}$, Angela H. Arthington ${ }^{3}$, Michael McClain ${ }^{4}$, Nicholas Bond ${ }^{5}$, Mike Acreman ${ }^{6}$, Barry Hart ${ }^{7}$, Michael J. Stewardson ${ }^{1}$, Brian Richter ${ }^{8}$ and N. LeRoy Poff ${ }^{9,10}$

${ }^{1}$ Environmental Hydrology and Water Resources Group, Department of Infrastructure Engineering, The University of Melbourne, Melbourne, VIC, Australia, ${ }^{2}$ Law School, The University of Melbourne, Melbourne, VIC, Australia, ${ }^{3}$ Australian Rivers Institute, Griffith University, Nathan, QLD, Australia, ${ }^{4}$ Institute for Water Education, IHE Delft, Delft, Netherlands, ${ }^{5}$ The Murray Darling Freshwater Research Centre, Wodonga, VIC, Australia, ${ }^{6}$ Centre for Ecology \& Hydrology, Wallingford, United Kingdom, ${ }^{7}$ Water Science, Echuca, VIC, Australia, ${ }^{8}$ Sustainable Waters, Crozet, VA, United States, ${ }^{9}$ Department of Biology, Colorado State University, Fort Collins, CO, United States, ${ }^{10}$ Institute for Applied Ecology, University of Canberra, Canberra, ACT, Australia
\end{abstract}

OPEN ACCESS

Edited by:

David Tickner,

World Wide Fund for Nature (United Kingdom), United Kingdom

Reviewed by:

Bradley James Pusey,

Charles Darwin University, Australia

Nitin Kaushal,

World Wide Fund for Nature, India

Nathanial Matthews,

Consultative Group on International Agricultural Research (CGIAR), United States

${ }^{*}$ Correspondence: Avril C. Horne

Avril.horne@unimelb.edu.au

Specialty section

This article was submitted to

Freshwater Science,

a section of the journal

Frontiers in Environmental Science

Received: 28 August 2017 Accepted: 29 November 2017 Published: 14 December 2017

Citation:

Horne AC, Webb JA, O'Donnell E, Arthington AH, McClain M, Bond N, Acreman M, Hart B, Stewardson MJ,

Richter B and Poff NL (2017)

Research Priorities to Improve Future Environmental Water Outcomes.

Front. Environ. Sci. 5:89.

doi: 10.3389/fenvs.2017.00089
Significant progress in environmental flow management has occurred in recent years due to several factors. These include governments committing to environmental flow programs, significant progress in scientific understanding, and environmental flow assessment methods that are cognizant of stakeholder participation and co-design. However, there remain key challenges facing environmental water management. In this paper, we report on a horizon scanning exercise that identified the questions, which, if answered, would deliver much needed progress in the field of environmental water management. We distributed an online survey to ask researchers and practitioners in the field of environmental water management to identify the key questions. The authors then consolidated 268 submitted questions and organized them into key themes. The consolidated list was presented to a workshop of environmental water researchers and practitioners, where attendees were asked to review the questions, vote on the most important, and provide feedback on gaps, issues, or overlaps. The breadth of issues facing environmental water management is captured by the six key themes into which questions were classified: (1) Ecological knowledge and environmental flow assessment methods, (2) Adaptive management, (3) Integrated management and river objectives, (4) Knowledge transfer: applying best practice in a global context, (5) Community knowledge and engagement, and (6) Active management. These questions provide a roadmap for research and management innovations that will improve the effectiveness of environmental flows programs.

Keywords: environmental flows, environmental water, horizon scanning, adaptive management, active management

\section{INTRODUCTION}

Aquatic ecosystems and freshwater biodiversity are in decline worldwide (Dudgeon et al., 2006). Continued population growth and changing life styles, coupled with climate change, will only increase competition for scarce water resources in many regions in the future, with commensurate increases in the threats to aquatic ecosystems (Meyer et al., 1999; Poff et al., 2002), and in some 
cases significantly modifying current river ecosystems and generating hybrid and novel systems (Acreman et al., 2014; Laizé et al., 2017). Environmental water management aims to respond to these threats by both protecting and where necessary restoring flow regimes to support aquatic ecosystem function and biodiversity (Meyer et al., 1999; Poff et al., 2002). In 2007, the Brisbane Declaration established an international consensus on the definition of environmental flows, as "the quantity, timing, and quality of water flows required to sustain freshwater and estuarine ecosystems and the human livelihoods and wellbeing that depend on these ecosystems" (emphasis added). As a result, environmental flows assessments have expanded from site-specific scientific studies to holistic studies that recognize the links between hydrology, ecosystem condition, societal expectations, and socio-economic outcomes. The Brisbane Declaration called for commitment to a number of key actions to restore and maintain environmental flows, many of which were aimed at expanding the number of locations where environmental flows are implemented, broadening stakeholder engagement, and enhancing the capacity required to implement and maintain environmental flows (Brisbane Declaration, 2007).

It is now 10 years since the Brisbane Declaration and there has been clear progress on a number of fronts. First, the concept of environmental flows and "environmental water management" has been widened to reflect the sentiments of the Brisbane Declaration. Environmental flow assessment methods are now cognizant of stakeholder participation and co-design, and recognize the dual role of environmental water in supporting ecological and social values, especially for those who rely on rivers and floodplains to support their livelihood (King and Brown, 2010; Finn and Jackson, 2011). Second, there has been significant progress in our understanding of the scientific concepts and ecological processes that underpin environmental flows (Arthington et al., 2006; Horne et al., 2010; Arthington, 2012; Acreman et al., 2014), and third, environmental water requirements have now been discussed and incorporated into high-level water policy and legislation in many countries across the globe (Hirji and Davis, 2009; Le Quesne et al., 2010; O'Donnell, 2014). This latter development is reflected in the growing number of government agencies and non-government entities funding environmental water projects (Garrick et al., 2011; Pahl-Wostl et al., 2013), and the large sums expended on river flow restoration projects. We have also recently seen the first cases of rivers being granted the same legal status as a person and with the same rights - the Whanganui River in New Zealand, the Ganga and Yamuna Rivers in India (currently stayed pending the outcome of an appeal to the Supreme Court), and Himalayan glaciers, rivers, streams, lakes, and forests (O'Donnell and Talbot-Jones, 2017). Collectively, the establishment of these new legal persons represents the most significant creation of new legal rights for nature since 2010, when Bolivia passed the Law of Rights of Mother Earth (Plurinational State of Bolivia, 2010).

Despite this progress in the science, policies and legislation of environmental flows, cases of implementation have been limited, There remain key challenges facing environmental water management, especially in response to the rapid socio-economic and environmental changes currently affecting rivers in many regions of the globe (Poff and Matthews, 2013; Rockström et al., 2014; Zarfl et al., 2015). In this horizon scanning exercise, we identify and discuss the big questions, which, if answered, would deliver significant progress in the field of environmental water management, and would underpin the next wave of efforts to protect and restore these most important aquatic ecosystems.

\section{METHODS}

Horizon scanning exercises like the one discussed here provide a useful reference of the current state of the discipline, and help to set the agenda for future research efforts (Sutherland et al., 2006). Past horizon scanning studies in the environmental science field have identified questions using some combination of: (1) a survey to gather as wide a range of opinions in the field as possible, (2) a workshop, and (3) a review process (Sutherland et al., 2006, 2013; Rudd et al., 2011; Parsons et al., 2014; Seddon et al., 2014). We used all three stages of this sequence.

We developed an online survey, the link for which was distributed through the authors' existing professional and research networks. The survey link was also distributed to authors of papers from Environmental Flows sessions at the International Symposium on Ecohydraulics (ISE), the community for the conference at which the later workshop took place. Receivers of the email were also asked to distribute it to their own networks, so the total number of recipients would have been larger. The survey asked researchers and practitioners in the field of environmental water management to identify:

"What questions, if answered, would allow the biggest progress in the field of environmental water management?"

Respondents were asked to think globally, with no limitation on the scope of the questions, so they could be broad high level questions, or very specific questions.

We then reviewed the survey responses and identified overlaps in content. The questions were consolidated into a smaller list (included in this paper) and organized into key themes. Classification of the questions drew on the diverse and extensive experience of the authors. For example, although many individual questions related to the theme of climate change, the authors considered that climate change is an issue that needs consideration as part of all elements of environmental water management. Thus, climate change has been integrated into all themes rather than being a single theme.

The consolidated list was presented at a workshop conducted during the 11th ISE meeting, held in Melbourne, Australia, in February 2016 (Webb et al., 2016). This international conference drew delegates from over 30 countries, and environmental water management was one the key foci, including several sessions dedicated to this topic. Further, unlike many other conferences that deal with environmental flow science, this conference spans a range of disciplinary perspectives and extends from science to practice. The workshop attracted approximately 40 participants. Questions were arranged into themes, with each theme's questions posted in a different part of the room. Participants were conducted around the room and took place in 
a discussion facilitated by two of the authors (JAW, ACH) about each theme and question to maximize shared understanding. Participants were asked to review the questions, vote on the most important, and provide feedback on gaps, issues, or overlaps. This paper is based on the questions identified through the survey, refined through the workshop, and complemented by insights and discussions during manuscript preparation.

There are clear limitations in any exercise of this kind. The questions identified will be closely linked to the geographies and disciplines of those involved in the survey. We attempted to mitigate these effects though the multi-step approach, and through the inclusion of a range of backgrounds, specializations, sectors, and locations, but there will no doubt remain some inadvertent bias. However, as seen in the results section, some regions are underrepresented in the survey (e.g., South America, North America and Africa). This is likely due to the distribution lists used for the survey which may have placed greater emphasis on Australia and Oceania. Similarly, there is a greater representation of ecology and hydrology which reflects the dominance of these disciplines more broadly in the science and practice of environmental flows. Importantly, the authors for this journal paper include a broad cross-section, both in terms of geography and discipline to ensure a broad and balanced perspective in the interpretation of the study results. However, a limitation of such horizon scanning exercises is the sample of opinions included in the process. Despite these limitations, this overview provides a valuable snapshot of the big issues for future environmental water management and offers a challenging and timely re-assessment of future research agendas.

\section{RESULTS}

Sixty-five individuals responded to the survey, providing a total of 268 questions. A full list of questions obtained through the survey is provided in Supplementary Material. Approximately half of the respondents identified themselves as practitioners, and $61 \%$ identified themselves as researchers (i.e., some respondents identified as both). The majority of respondents were ecologists and hydrologists, with a smaller number of engineers, lawyers, economists and social scientists. The majority of respondents were from Europe (27) and Oceania (24), with smaller numbers from North America (8), Africa (3), and Asia (3).

The original questions were consolidated into 57 questions, which were classified into six themes that cover the full range of the environmental water management cycle (Horne A. et al., 2017b). The environmental water management cycle includes establishing a vision and objectives for the river (through broad stakeholder engagement), the science of determining the flow regime needed to achieve the objectives, legal and institutional arrangements to allocate and manage the water, and monitoring, evaluation and adaptive management. During the workshop, 10 questions received much larger numbers of votes than the other 47, demonstrating their importance for workshop participants. Below, these questions have been highlighted and are discussed in detail. The other questions for each theme are presented in boxed text, and are not listed in any particular order.

\section{Ecological Knowledge and Environmental Flow Assessment Methods}

At the heart of any environmental flow assessment method lies a need for knowledge of how the ecology of a system has been affected by past human-induced changes in flow regimes, and how it may respond to the partial or full restoration of particular flows. Both the lack and inconsistency of generalizable empirical relationships linking flow changes to ecological response (Poff and Zimmerman, 2010) has seen the predominance of expertbased predictions of ecological response becoming embedded in major environmental flow assessment frameworks (Horne et al., 2010). Recognizing the limitations of such frameworks, river scientists have emphasized the need for empirical flow-response relationships for use in assessments (Arthington et al., 2006; Poff and Zimmerman, 2010; Davies et al., 2014). Even so, most of these recent efforts are still largely based on relatively simple ecohydrological models (Webb et al., 2017). Our respondents and workshop participants concluded that there is still much work required with regard to basic knowledge of river ecology and how to incorporate such knowledge into environmental flow assessments, implementation, and management.

Q1-Can we demonstrate clear quantitative links between the ecology of aquatic species and alterations in hydrology or hydraulics at different spatial and temporal resolutions, and develop appropriate models of these relationships?

Although our understanding of flow-ecology relationships has significantly improved over the past 20 years (Arthington, 2012), there remain substantial gaps in our knowledge of the ecological effects of flow alterations (Poff and Zimmerman, 2010; Webb et al., 2013). River ecosystems are influenced by a wide range of factors, including species interactions, temperature, and sediment dynamics, that may interact in numerous unspecified ways with flow alteration (Acreman et al., 2014). With much research still reliant on drawing patterns from uncontrolled changes in flow conditions during floods or droughts, a major challenge is to undertake controlled water management experiments at the catchment scale (Konrad et al., 2011; Olden et al., 2014). More collaboration between dam owners/operators, landholders, and scientists is needed to codevelop hypotheses and provide robust tests of these via flow manipulation experiments (Poff et al., 2003). This need to improve our basic understanding of ecological relationships with flow is reflected in Question 1, and the other questions identified below sit under this higher level challenge.

Q2-Can we determine ecosystem resilience, and thresholds that lead to a major change in ecological condition (or state) (i.e., can failure points be identified)?

Current environmental flow assessment methods hinge on the assumption of a stationary climate (i.e., long term average climate conditions with variation) (Poff and Matthews, 2013). It is now recognized that the climate is changing and future hydrologic regimes are likely to deviate substantially from historical reference conditions in many regions (e.g., Reidy Liermann et al., 2012). 
BOX 1 | Other key questions for ecological knowledge and environmental flow assessment methods.

- What is the current condition and biodiversity of our rivers worldwide?

- Are organisms adapting to altered hydrological and geomorphological regimes? We assume in our habitat suitability approaches that organisms have preferences that, when not available, permanently diminish their performance and success. How strong is the evidence for this assumption?

- What is the time to, and duration of, ecosystem responses to prescribed environmental flows and what factors affect recovery rate from flow alteration?

- What is an appropriate reference condition in altered systems (altered through for example climate change, significant channel modification or regulating infrastructure)?

- What is an appropriate flow assessment methodology for an ephemeral stream or intermittent river?

- What are the best methods and tools for environmental flow assessments in under-allocated ${ }^{1}$. (rather than over-allocated) systems?

- How should multiple stressors be considered in environmental flow assessment and management?

- How do we better include the role of temperature and water quality in environmental water assessments and desirable outcomes and how will this change under scenarios of climate change?

- Are we adequately considering sediment inputs to streams and their role in hindering and enhancing ecological response?

- How do we identify and create system-scale protected areas that conserve key processes and functions?

- How do we relate broad scale water management issues with protection of habitat and conservation of biodiversity at local scales?

- When is it appropriate to transfer eco-hydrological knowledge between river systems? How do we extrapolate monitoring and evaluation outcomes from one area to another area that has not been monitored?

- What research methods will allow us to use site-scale data to inform large-scale responses to environmental flows, and include these in decision making?

Hybrid and novel ecosystems are likely to be created (Acreman et al., 2014; Moyle, 2014; Laizé et al., 2017). An understanding of ecological thresholds and resilience will become increasingly important as climate change further impacts river flow regimes and ecosystems (Rockström et al., 2014). This will require specific research to understand the resilience and reversibility of particular environmental systems (Groffman et al., 2006; Capon et al., 2015).

Further key questions on Ecological knowledge and environmental flow assessment methods are shown in Box 1.

\section{Adaptive Management}

Adaptive management centers on iterative learning and feedback to change management strategies (Allen and Garmestani, 2015; Webb et al., 2017). Adaptive management is wellsuited to problems such as environmental water management, where the outcomes are responsive to management, there is uncertainty about the impacts of management, and yet decisions must still be made (Williams and Brown, 2014). There are multiple sources of uncertainty affecting environmental water management, including climatic uncertainty affecting future water availability and demands for consumptive use, and scientific uncertainty concerning ecological responses to changing patterns of flow variability (Lowe et al., 2017). While many environmental water agencies and policy documents refer to adaptive management, there are few documented examples of its successful implementation (Westgate et al., 2013).

Q3-How do we progress adaptive management processes beyond simply meeting targets toward learning and feedback?

\footnotetext{
${ }^{1}$ In this context, an under-allocated system refers to a system where it may still be possible to increase consumptive water use and retain ecological values of the river. An over-allocated system is one where water abstractions or flow regulation is significantly impacting on the environmental values of the river and a rebalance is required.
}

One of the key benefits of adaptive management is its potential to facilitate learning through a structured dialogue between scientists, citizens, and managers (Pahl-Wostl et al., 2007; Ladson, 2009). However, a preoccupation with meeting targets largely limits environmental water management to an auditbased view of success or failure and does not sufficiently value learning. Related to this is the significant challenge for adaptive management of establishing the legitimacy of the environmental water program to operate within institutional settings that allow both success and failure, and therefore maximize the rate of learning. Getting the institutional arrangements correct will be essential to the success of adaptive management (Ladson, 2009). This may require fostering relationships across institutions that bring different skills and incentives (Westgate et al., 2013).

Q4-How to determine (and fund and maintain) an adequate monitoring, evaluation, reporting, and feedback system within an adaptive management cycle to measure hydrology, hydraulics, etc., and the ecological response to environmental flow regimes?

Monitoring and evaluation form an essential, but often timeconsuming and expensive, aspect of adaptive management (Williams and Brown, 2014). Without monitoring, there can be no adaptive learning, no way to complete the adaptive management cycle, and no way to update future management in light of new knowledge. One reason identified for the failure of adaptive management is the unfortunately common lack of commitment to monitoring and evaluation by management agencies (Schreiber et al., 2004). Monitoring and evaluation programs need to support both short-term implementation and long-term planning of environmental water programs and must be designed to distinguish flow-related impacts from multiple other pressures affecting ecosystem state and function (see also section Integrated Management and River Objectives). The design, funding, and administration of such monitoring and evaluation programs needs to be identified as early as 
BOX 2 | Other key questions for adaptive management.

- How do we operationalize evidence-based environmental water management? How do we translate research evidence into the decision-making processes?

- How can adaptive management approaches best be applied to implementation of environmental flows? Do the text book approaches suit environmental water management?

- How do we capture and disseminate the learnings and lessons from "informal adaptive management"? How can we legitimize this approach?

- How do we maintain support and funding to allow the completion (many times) of the adaptive management loop of plan-implement-measure-respond?

possible, and a commitment made to long-term engagement (Davies et al., 2014). Moreover, a framework needs to be in place to incorporate the lessons from monitoring outcomes and evaluation into updated management practices (Webb et al., 2017). Exploring options to enhance the resourcing, local support and implementation of monitoring and evaluation (e.g., Liu et al., 2014) has the potential to allow adaptive management to occur in places where it may otherwise be neglected. Informal adaptive management (Allan and Watts, 2017) may emerge spontaneously in systems where there is trust and good communication between stakeholders, but no formal process in place.

Further key questions on Adaptive management are shown in Box 2.

\section{Integrated Management and River Objectives}

It must be emphasized that environmental water needs should be considered as a core part of water planning, water infrastructure design and operations, and overall catchment management, rather than independently (Hirji and Davis, 2009). However, while there are approaches that embed environmental flows within broad catchment management (King and Brown, 2010), these decisions are often made somewhat in isolation of one another (Horne A. et al., 2017a), ignoring the well documented effects of other catchment stressors that may act independently or interactively with flows (Jakeman and Letcher, 2003). Post-hoc evaluation of environmental water projects has often identified co-occurring stressors as responsible for underachievement from environmental water delivery (Rolls et al., 2012; Mackie et al., 2013). Failure to manage co-occurring stressors in an integrated fashion is partly a function of how catchment and water management agencies have developed over time, but is also partly driven by the different rates at which decision-making processes for different water and catchment uses have evolved over time. Truly integrated catchment management (sensu Smith et al., 2015) would be a major step forward for all stakeholders.

\section{Q5-How can environmental flows be better integrated into mainstream water resource planning, flood and drought management, river operations and infrastructure planning, balancing the needs of people and ecosystems?}

Environmental water is often seen as competing for water with consumptive water users, however, providing environmental flows greatly enhances water security for other users (Tickner and Acreman, 2013; Tickner et al., 2017) and there are significant opportunities to design infrastructure and water delivery to consider environmental water requirements (Poff et al., 2016). Considering environmental water management decisions in isolation from other water management tasks is unlikely to optimize water use across all stakeholders. Where water infrastructure is being planned, opportunities exist to avoid or minimize potential socio-ecological impacts of this infrastructure at a system scale, particularly through appropriate dam placement (Opperman et al., 2015; Winemiller et al., 2016) and the use of dam design features and operational rules that enable environmental water delivery (Poff et al., 2016; Thomas, 2017). These opportunities are rarely available for existing infrastructure that was developed in isolation without consideration of environmental water needs. Environmental flows usually aim to consider all aspects of the flow regime, not just quantity One feature of critical importance to river functions is inundation of floodplain areas and wetland ecosystems (Yarnell et al., 2015). Environmental water management needs to maintain these critical ecosystem processes through the integration of high flow events with flood management for protection of infrastructure and floodplain uses (Acreman et al., 2009; Arthington, 2012). Drought management also presents significant challenges, including protection of refuge habitats for aquatic biota at landscape scale, and options to provide environmental flows in critical river reaches (Bond et al., 2008).

Q6- How can we improve the management of consumptive water to help meet environmental objectives?

Ideally, the governance structure for managing water resources would encourage development of approaches that maximize shared benefits for both environmental and other water users (for example, by managing water delivery to maximize both consumptive and environmental outcomes, such as enabling river operators to use irrigation or hydro-power water delivery to meet environmental flow requirements). However, environmental water management is often isolated from water management more broadly. This limits the capacity for novel integrated solutions to emerge, and for effective policy debate (Dalal-Clayton and Bass, 2009).

This problem is exacerbated by current institutional boundaries that delineate the environment as separate to productive uses of water, and which can reinforce a competitive mind set between these purposes. For example, although the creation of water rights for the environment in Australia and the western USA has increased the volume of environmental water and improved environmental outcomes (Garrick et al., 2009), it has done so by constructing the environment as just another user of water (O'Donnell, 2017). In Australia, the Commonwealth Environmental Water Holder frequently refers 
to itself as the largest irrigator in the basin (Docker, 2013). Rather than enabling a collaborative approach that can deliver shared benefits to both the environment and irrigators, this framing places the environment's need for water in direct competition with "other" irrigators' needs. Although these environmental water rights (which are often legally very similar and in some cases identical to irrigator water rights), and the organizations that manage them, have been an important step forward in improving environmental water management, they have also increased the institutional separation between water planning more broadly, and managing water for the environment.

Q7-What changes will be needed to environmental objectives and water allocation frameworks to support environmental water management under climate change? How are climate change risks distributed amongst water users?

As climate change continues to impact upon water availability, major policy discussions will be required to consider how changes in resource availability are to be distributed amongst water users, and what changes may be required to river basin objectives (Acreman et al., 2014). Integration of environmental water consideration into existing consumptive water management activities requires new tools, skills and governance arrangements for water management institutions. These institutional arrangements and environmental water allocation mechanisms need to reflect conscious decisions concerning how water resources will be managed adaptively over time (Horne A. C. et al., 2017b; O’Donnell and Garrick, 2017b).

Further key questions on Integrated management and river objectives are shown in Box 3.

\section{Knowledge Transfer: Applying Best Practice in a Global Context}

There have been few attempts to systematically assess the global experience on implementation and effectiveness of environmental watering under different levels of development, administrative settings, and political systems (Pahl-Wostl et al., 2013). The challenge and urgency of protecting water regimes is global, but significant advances in environmental water science, policy, and practice have been unevenly distributed among countries and biophysical, social, cultural, and political settings (McClain and Anderson, 2015). A present-day cartogram of published research efforts on environmental flows would be heavily skewed toward North America, Europe, and Australia (Poff and Zimmerman, 2010; Konrad et al., 2011).

Q8-What are the best methods and tools for environmental flows assessment and implementation in developing countries?

Many developing countries are grappling with the challenges of poverty alleviation, human well-being, and rapid economic development. In such settings there is a need for relatively simple methods that can be used to quantify environmental flow needs in a quick, transparent, and repeatable fashion. Direct and indirect human needs must form an important component of this assessment (Christie et al., 2012). While it is not possible to outline specific approaches in detail here, we highlight the importance of several key elements, including the need to elicit and synthesize local indigenous knowledge together with scientific information where it is available (see Q10), the need to characterize key aspects of the natural flow regime, especially seasonality and inter-annual variability, and the use of conceptual models to identify important components of the flow regime that warrant some degree of protection in order to sustain biophysical processes. Numerous "hydrology only" methods have been developed, which can also be used in a precautionary sense to try and set limits on hydrologic alteration. Arguably the initial goal should be to ensure some degree of flow-regime protection to help prevent irreversible ecological impacts (Richter et al., 2012), until such time that there are policy and funding frameworks in place to support the refinement of sustainable long-term watersharing arrangements among various competing and compatible users (including the environment).

BOX 3 | Other key questions for integrated management and river objectives.

- How will water resource availability in both surface water and groundwater systems change into the future (climate change, landuse change, interception), and how will changes in water availability impact environmental water management?

- Should environmental flows be managed for restoration of particular elements (species, processes) or for adaptive potential (i.e., management for ecosystem resilience)?

- What is the best approach to determining how much water can be sustainably extracted from a river (e.g., by setting a resource cap)?

- How can environmental outcomes be better represented in trade-off decisions where there are different kinds of information about the benefits in economic terms?

- How can the costs of providing environmental flows and the benefits of ecosystem services be better quantified to support water allocation decisions?

- How can environmental flows be more effectively integrated with other natural resource management activities, such as riparian restoration and the management of invasive alien species?

- How can we build complementary works (e.g., habitat restoration, effects of barriers, invasive species management) into the evaluation framework for environmental flows and future management decisions?

- How can we better understand and address the impacts of increased urban stormwater on urban waterways?

- How do we manage the risk of private property flooding (third party impacts) when providing large events for floodplain inundation?

- How can effective resource caps be implemented where systems are managed across agencies or jurisdictional boundaries?

- What is the best approach to assess how well environmental water is allocated and protected through governance arrangements, policy, and legislation?

- How should we embed environmental flows into the food-energy-water-ecosystem nexus, and the Sustainable Development Goals? 
BOX 4 | Other key questions for knowledge transfer: applying best practice in a global context.

- How many countries have included environmental water needs into formal legislation and how is this achieved?

- What models of environmental water governance exist around the world and what can we learn from them?

- What models for embedding environmental flows in water allocation mechanisms are used around the world and how effective are they?

- How can we undertake quick and cost-effective (but still robust) environmental flow assessments in knowledge poor systems?

- Can a better understanding of ecosystem services contribute to implementation of environmental flows in developing countries?

- Are there innovate funding mechanisms that can help secure more water for environmental flows and their management?

- How do we facilitate a rapid response to the decline of aquatic biodiversity?

BOX 5 | Other key questions for community knowledge and engagement.

- How do we build a broader, deeper community engagement in and support for environmental water?

- How do we communicate concepts of uncertainty and variability in the context of environmental water management and outcomes without undermining public support?

- How can centralized 'top down' decision making best be integrated with localized 'bottom up' decision making in environmental water management?

- How should the concept of efficiency (i.e. least cost transactions) be balanced with legitimacy (public support and consultation) for environmental water management organizations?

- How can indigenous and local knowledge be incorporated into environmental flow visions, planning, implementation and adaptive management?

Further key questions on Knowledge transfer are shown in Box 4.

\section{Community Knowledge and Engagement}

A central element of sustainable water management is establishing a shared vision for the river system, acknowledging the diverse uses of the resource, and recognizing the variety of ways that different cultures value the natural environment. The amount of water needed by a river is inherently linked to what type of river and ecological services the stakeholder community wants. The benefits of stakeholder participation in policy and management are well-recognized, leading to a better quality of decision, better acceptance of decisions and development of social capital (Poff et al., 2003; von Korff et al., 2012). This type of legitimacy is crucial to the long-term success of environmental water programs, ranking alongside efficiency and effectiveness as the core elements of good water governance (OECD, 2015).

Q9-How can a more effective partnership between all stakeholders-government, communities, NGOs, and scientists-be developed?

Effective stakeholder engagement requires the involvement of multiple groups, and respect for their different sources of knowledge, values, and visions for aquatic ecosystems. Building a meaningful partnership between stakeholders in which all are committed to achieving successful enviornmental water management takes time, effort, trust, and humility (Horne A. C. et al., 2017a). However, there remain two clear challenges that require novel approaches, these being: (a) the implemention of participatory approaches in practice (Creighton, 2005), and (b) measuring how successful these have been (O'Donnell and Garrick, 2017a).
Q10-How best to build a shared understanding among all stakeholders (including scientists)?

One of the profound shifts in the environmental flows assessment process has been the transition from a purely technical ecological and hydrological assessment, to the inclusion of local communities and their values from the outset (Poff et al., 2003; Rogers, 2006; Finn and Jackson, 2011). Frameworks emerged in South Africa that considered the implications of management scenarios for the people dependent on a river's natural resources (King et al., 2003; Arthington, 2012). However, this process of engagement can become fragmented after the initial environmental flows studies are complete. The management of environmental water is an ongoing process, and the adaptive management and learning processes need to include continued dialogue between local communities, practitioners and researchers. There is a particular challenge to integrate and value local and indigenous knowledge and perspectives with knowledge derived from researchers and technical agencies (Finn and Jackson, 2011; Tan and Jackson, 2013; Tan and Auty, 2017).

Further key questions on Community knowledge and engagement are shown in Box 5.

\section{Active Management}

Increasingly, mechanisms that require active and ongoing decision making by environmental water managers are being used to allocate environmental water, particularly in systems that have high levels of abstractive demands and hydrological alteration. The Murray-Darling Basin, Australia, is perhaps the most notable example of this. By active management, we mean systems where environmental water managers hold a right to water and are required to make particular decisions about when and where to release environmental water from storage to achieve the best possible environmental outcomes (Doolan et al., 2017; Horne A. C. et al., 2017c). In other management settings it may 
BOX 6 | Key questions for active management.

- How can variability and sequencing of flow events and recovery of species be better integrated into environmental flow assessment methodologies?

- Can we mimic elements of the natural cycle of variability rather than attempting to optimize across all environmental endpoints in all years?

- What is the marginal improvement in biological conditions from incremental change in stream flow or water level (or from one flow component over another) at different stream locations?

- How should ecosystem sensitivity, resilience and recovery rates be incorporated into decision making?

- What tools or prioritization process would support decision-making and trade-offs between environmental water regimes that have different objectives (considering also the water preferences of invasive species)?

- What governance arrangements are suited to the real-time management decisions required for active management?

mean shifting between predefined conditions (wet or dry) that have distinct environmental flow values associated with them (King et al., 2008). These dynamic and reactive decisions require more information from the scientific community concerning the marginal benefits of providing water at a particular time and location, and the sequencing or interaction between flow events and ongoing environmental condition (Horne A. C. et al., 2017c). There is a challenge in linking these short term active decisions to longer term objectives of resilience, with short term and long term management strategies aligned (Poff, 2017). Active management is a new challenge linked to novel allocation mechanisms for environmental water management (Horne A. C. et al., 2017b; O’Donnell and Garrick, 2017b), and although none of the questions relating to active management were given a top-10 ranking, the authors consider this to be a key emerging theme for research in an ever more water-contested and unpredictable future.

Active management is resource intensive. It requires a tradeoff between the flexibility and autonomy of these sorts of allocation mechanisms and the expense of ongoing management. It is not yet clear which sorts of river systems are best served by this model.

Key questions on Community knowledge and engagement are shown in Box 6.

\section{CONCLUSIONS}

The future in front of us is well summarized by the following quotation-"Our future advances will not be concerned with universal laws, but instead with universal approaches to tackling particular problems, and with general theoretical insights about the surprises that may ambush us if we think too narrowly." (Kareiva, 2011).

The questions identified in this study cover the full diversity of environmental water policy, science, and practice. The discipline of environmental water management has traditionally been driven from the perspectives of ecology and hydrology, with somewhat separated lines of research around social and institutional aspects of environmental water management (Poff and Matthews, 2013). The results presented in this paper highlight the benefits that would accrue from a more multidisciplinary and inclusive approach in environmental water research and management. This perspective is in keeping with the recognition that sustaining river health and resilience is the foundation for achieving human water security, and with the need to develop infrastructure and institutional arrangements that allow multiple outcomes for society (Tickner et al., 2017).

The questions identified highlight the importance of continuing to develop our fundamental understanding of how natural flow variability influences riverine and other riverdependent ecosystems such as floodplains and wetlands. This has in many ways been the motivation for much of the progress in environmental flows to date (Bunn and Arthington, 2002; Lytle and Poff, 2004). However, our questions also highlight the disconnect between the processes of knowledge generation and the uptake or translation into management processes and adaptive learning.

As environmental water management transitions further into an implementation phase, the institutions and processes that link various stakeholders, and govern the process of allocating and managing environmental water, become vitally important. There is a growing body of work that examines the legal, regulatory and organizational tools for the allocation and management of environmental water (Godden, 2010; Foerster, 2011; PahlWostl et al., 2013), but to date, there has been insufficient work integrating this research into the mainstream environmental flows literature. The OECD recognized in 2015 that water crises were fundamentally crises of governance (OECD, 2015), and environmental water managers need to heed this lesson. Strong institutions underpin accountability, transparency and support efficiency, efficacy and legitimacy of environmental water management (O'Donnell and Garrick, 2017a). As increasing volumes of environmental water are allocated, the importance of institutions and governance and their vital roles will continue to grow.

Many of these challenges will be ongoing and constantly refined (as will the fundamental ecological research). Rather than providing "an answer" this paper has sought to stimulate improvements in the scientific basis and robustness of the entire environmental water management cycle, and new approaches to be able to cope with changing attitudes, environmental conditions, scenarios and priorities. This perspective is highlighted through the themes described above, which are about learning, sharing knowledge and engaging all stakeholders in the complex processes of the water management cycle.

\section{AUTHOR CONTRIBUTIONS}

$\mathrm{AH}, \mathrm{JW}, \mathrm{MA}, \mathrm{MS}$, and BR: designed the survey and structure of the paper; $\mathrm{AH}$ and JW: analyzed the 
survey and ran the workshop; All authors contributed to discussions on the key questions and writing of the article.

\section{FUNDING}

AH was funded through an Australian Research Council Linkage Project (LP130100174) during the preparation of this paper. MA acknowledges funding from the UK Natural Environment Research Council.

\section{REFERENCES}

Acreman, M., Aldrick, J., Binnie, C., Black, A., Cowx, I., Dawson, H., et al. (2009). Environmental flows from dams: the water framework directive. Proc. ICE Eng. Sustainability 162, 13-22.

Acreman, M., Arthington, A. H., Colloff, M. J., Couch, C., Crossman, N. D., Dyer, F., et al. (2014). Environmental flows for natural, hybrid, and novel riverine ecosystems in a changing world. Front. Ecol. Environ. 12, 466-473. doi: $10.1890 / 130134$

Allan, C. A., and Watts, R. J. (2017). Revealing adaptive management of environmental flows. Environ. Manage. doi: 10.1007/s00267-017-0931-3. [Epub ahead of print].

Allen, C. R., and Garmestani, A. S. (eds.). (2015). "Adaptive management," in Adaptive Management of Social-Ecological Systems (Dordrecht: Springer Science), 1-10.

Arthington, A. H. (2012). Environmental Flows: Saving Rivers in the Third Millennium. Berkeley: University of California Press.

Arthington, A. H., Bunn, S. E., Poff, N. L., and Naiman, R. J. (2006). The challenge of providing environmental flow rules to sustain river ecosystems. Ecol. App. 16, 1311-1318. doi: 10.1890/1051-0761(2006)016[1311:TCOPEF]2.0.CO;2

Bond, N. R., Lake, P. S., and Arthington, A. H. (2008). The impacts of drought on freshwater ecosystems: an Australian perspective. Hydrobiologia 600, 3-16. doi: $10.1007 / \mathrm{s} 10750-008-9326-\mathrm{z}$

Brisbane Declaration (2007). "Environmental flows are essential for freshwater ecosystem health and human well-being," in 10th International River Symposium and International Environmental Flows Conference (Brisbane, QLD).

Bunn, E. S., and Arthington, A. (2002). Basic principles and ecological consequences of altered flow regimes for aquatic biodiversity. Environ. Manage. 30, 492-507. doi: 10.1007/s00267-002-2737-0

Capon, S. J., Lynch, A. J. J., Bond, N., Chessman, B. C., Davis, J., Davidson, N., et al. (2015). Regime shifts, thresholds and multiple stable states in freshwater ecosystems; a critical appraisal of the evidence. Sci. Total Environ. 534, 122-130. doi: 10.1016/j.scitotenv.2015.02.045

Christie, M., Cooper, R., Hyde, T., and Fazey, I. (2012). An evaluation of economic and non-economic techniques for assessing the importance of biodiversity and ecosystem services to people in developing countries. Ecol. Econ. 83, 67-78. doi: 10.1016/j.ecolecon.2012.08.012

Creighton, J. L. (2005). The Public Participation Handbook: Making Better Decisions Through Citizen Involvement. San Francisco, CA: Jossey-Bass.

Dalal-Clayton, B., and Bass, S. (2009). The Challenges of Environemtnal Mainstreaming - Experience of Integrating Environment into Development Institutions and Decisions. London: International Institute for Environment and Development.

Davies, P. M., Naiman, R. J., Warfe, D. M., Pettit, N. E., Arthington, A. H., and and, Bunn, S. E. (2014). Flow-ecology relationships: closing the loop on effective environmental flows. Mar. Freshw. Res. 65, 133-141. doi: 10.1071/MF13110

Docker, B. (2013). "Discussion paper Topic 1: Structural Issues and the "Big Picture": What Institutional Mechanisms and Legal Status Can and Should We Provide for Environmental Water as a "Partner" in Water Use?" in Mainstreaming Environmental Water Law and Policy Workshop, eds E. O'Donnell and R. Nelson (Melbourne, VIC: Melbourne Law School, Centre for Energy, Resources and Environment Law).

\section{ACKNOWLEDGMENTS}

We would like to thank the survey respondents for their time, consideration, and input to the paper.

\section{SUPPLEMENTARY MATERIAL}

The Supplementary Material for this article can be found online at: https://www.frontiersin.org/articles/10.3389/fenvs. 2017.00089/full\#supplementary-material

Doolan, J. M., Ashworth, B., and Swirepik, J. (2017). "Chapter 23: Planning for the active management of environmental water," in Water for the Environment, eds A. C. Horne, J. Angus Webb, M. J. Stewardson, B. Richter, and M. Acreman (Cambridge, MA: Academic Press), 539-561. doi: 10.1016/B978-0-12-803907-6.00023-1

Dudgeon, D., Arthington, A. H., Gessner, M. O., Kawabata, Z.-I., Knowler, D. J., Lévêque, C., et al. (2006). Freshwater biodiversity: importance, threats, status and conservation challenges. Biol. Rev. 81, 163-182. doi: $10.1017 /$ S1464793105006950

Finn, M., and Jackson, S. (2011). Protecting indigenous values in water management: a challenge to conventional environmental flow assessments. Ecosystems 14, 1232-1248. doi: 10.1007/s10021-011-9476-0

Foerster, A. (2011). Developing purposeful and adaptive institutions for effective environmental water governance. Water Resour. Manage. 25, 4005-4018. doi: 10.1007/s11269-011-9879-x

Garrick, D., Lane-Miller, C., and McCoy, A. L. (2011). Institutional innovations to govern environmental water in the western united states: lessons for Australia’s Murray-Darling Basin. Econ. Papers 30, 167-184. doi: 10.1111/j.1759-3441.2011.00104.x

Garrick, D., Siebentritt, M. A., Aylward, B., Bauer, C. J., and Purkey, A. (2009). Water markets and freshwater ecosystem services: policy reform and implementation in the columbia and murray-darling basins. Ecol. Econ. 69, 366-379. doi: 10.1016/j.ecolecon.2009.08.004

Godden, L. (2010). "Governing common resources: environmental markets and property in water," in Property and the Law in Energy and Natural Resources, eds A. McHarg, B. Barton, A. Bradbrook, and L. Godden (Oxford: Oxford University Press), 413-436.

Groffman, P. M., Baron, J. S., Blett, T., Gold, A. J., Goodman, I., Gunderson, L. H., et al. (2006). Ecological thresholds: the key to successful environmental management or an important concept with no practical application? Ecosystems 9, 1-13. doi: 10.1007/s10021-003-0142-z

Hirji, R., and Davis, R. (2009). Environmental Flows in Water Resources Policies, Plans and Projects: Findings and Recommendations. Washington: The International Bank for Reconstruction and Development/World Bank.

Horne, A., Kaur, S., Szemis, J., Costa, A., Webb, J. A., Nathan, R., et al. (2017a). Using optimization to develop a "designer" environmental flow regime. Environ. Model. Softw. 88, 188-199. doi: 10.1016/j.envsoft.2016.11.020

Horne, A., O’Donnell, E., Webb, J., Stewardson, M., Acreman, M., and Richter, B. D. (2017b). "The environmental water management cycle," in Water for the Environment: From Policy and Science to Implementation and Management, eds A. Horne, J. Webb, M. Stewardson, M. Acreman, and B. D. Richter (Cambridge, MA: Elsevier), 3-16.

Horne, A. C., O’Donnell, E. L., Acreman, M., McClain, M. E., LeRoy Poff, N., Angus Webb, J., et al. (2017a). "Chapter 27: Moving forward: the implementation challenge for environmental water management," in Water for the Environment, eds A. C. Horne, J. Angus Webb, M. J. Stewardson, B. Richter, and M. Acreman (Cambridge, MA: Academic Press), 649-673. doi: 10.1016/B978-0-12-803907-6.00027-9

Horne, A. C., O'Donnell, E. L., and Tharme, R. E. (2017b). "Chapter 17: Mechanisms to allocate environmental water," in Water for the Environment, eds A. C. Horne, J. Angus Webb, M. J. Stewardson, B. Richter, and M. Acreman (Cambridge, MA: Academic Press), 361-398. doi: 10.1016/B978-0-12-803907-6.00017-6 
Horne, A. C., Szemis, J. M., Webb, J. A., Kaur, S., Stewardson, M. J., Bond, N., et al. (2017c). Informing environmental water management decisions: using conditional probability networks to address the information needs of planning and implementation cycles. Environ. Manage. doi: 10.1007/s00267-017-0874-8. [Epub ahead of print].

Horne, A., Stewardson, M., Freebairn, J., and McMahon, T. A. (2010). Using an economic framework to inform management of environmental entitlements. River Res. Appl. 26, 779-795. doi: 10.1002/rra.1275

Jakeman, A. J., and Letcher, R. A. (2003). Integrated assessment and modelling: features, principles and examples for catchment management. Environ. Model. Softw. 18, 491-501. doi: 10.1016/S1364-8152(03)00024-0

Kareiva, P. (2011). Why worry about the maturing of a science? Available online at: http://www.nceas.ucsb.edu/nceas-web/projects/resources/ecoessay/brown/ kareiva.html

King, J., and Brown, C. (2010). Integrated basin flow assessments: concepts and method development in Africa and South-east Asia. Freshw. Biol. 55, 127-146. doi: 10.1111/j.1365-2427.2009.02316.x

King, J., Brown, C., and Sabet, H. (2003). A scenario-based holistic approach to environmental flow assessments for rivers. River Res. Appl. 19, 619-639. doi: 10.1002/rra.709

King, J. M., Tharme, R. E., and de Villiers, M. S. (2008). Environmental Flow Assessments for Rivers: Manual for the Building Block Methodology. Gezina: University of Cape Town.

Konrad, C. P., Olden, J. D., Lytle, D. A., Melis, T. S., Schmidt, J. C., Bray, E. N., et al. (2011). Large-scale flow experiments for managing river systems. Bioscience 61, 948-959. doi: 10.1525/bio.2011.61.12.5

Ladson, T. (2009). "Adaptive management of environmental flows - 10 years on," in Adaptive Environmental Management, eds C. Allan and G. H. Stankey (Dordrecht: Springer), 261-273.

Laizé, C., Acreman, M., and Overton, I. (2017). Projected novel ecohydrological river types for Europe. Ecohydrol. Hydrobiol. 17, 73-83. doi: 10.1016/j.ecohyd.2016.12.006

Le Quesne, T., Kendy, E., and Weston, D. (2010). The Implementation challenge Taking stock of Government Policies to Protect and Restore Environmental Flows. Surrey: The Nature Conservancy and WWF.

Liu, H.-Y., Kobernus, M., Broday, D., and Bartonova, A. (2014). A conceptual approach to a citizens' observatory - supporting community-based environmental governance. Environ. Health 13:107. doi: 10.1186/1476-069X-13-107

Lowe, L., Szemis, J., and Angus Webb, J. (2017). "Chapter 15: Uncertainty and environmental water," in Water for the Environment, eds A. C. Horne, J. Angus Webb, M. J. Stewardson, B. Richter, and M. Acreman (Cambridge, MA: Academic Press), 317-344. doi: 10.1016/B978-0-12-803907-6.00015-2

Lytle, D. A., and Poff, N. L. (2004). Adaptation to natural flow regimes. Trends Ecol. Evol. 19, 94-100. doi: 10.1016/j.tree.2003.10.002

Mackie, J. K., Chester, E. T., Matthews, T. G., and Robson, B. J. (2013). Macroinvertebrate response to environmental flows in headwater streams in western Victoria, Australia. Ecol. Eng. 53, 100-105. doi: 10.1016/j.ecoleng.2012.12.018

McClain, M. E., and Anderson, E. P. (2015). "The gap between best practice and actual practice in the allocation of environmental flows in integrated water resources management," in Sustainability of Integrated Water Resources Management, eds S. Setegn and M. Donoso (Cham: Springer), 103-120.

Meyer, J. L., Sale, M. J., Mulholland, P. J., and Poff, N. L. (1999). Impacts of climate change on aquatic ecosystem functioning and health. J. Am. Water Resour. Assoc. 35, 1373-1386. doi: 10.1111/j.1752-1688.1999.tb04222.x

Moyle, P. B. (2014). NOVEL AQUATIC ECOSYSTEMS: THE NEW REALITY FOR STREAMS IN CALIFORNIA AND OTHER MEDITERRANEAN CLIMATE REGIONS. River Res. Appl. 30, 1335-1344. doi: 10.1002/rra.2709

O'Donnell, E. (2014). "Common legal and policy factors in the emergence of environmental water managers," in Water and Society II, ed C. A. Brebbia (Southampton: WIT Press), 321-333.

O'Donnell, E. (2017). Constructing the Aquatic Environment as a Legal Subject: Legal Rights, Market Participation, and the Power of Narrative. Ph.D. University of Melbourne, Melbourne, VIC.

O’Donnell, E. L., and Garrick, D. E. (2017a). "Chapter 19: Environmental water organizations and institutional settings," in Water for the Environment, eds A. C. Horne, J. Angus Webb, M. J. Stewardson, B.
Richter, and M. Acreman (Cambridge, MA: Academic Press), 421-451. doi: 10.1016/B978-0-12-803907-6.00019-X

O'Donnell, E. L., and Garrick, D. E. (2017b). "Chapter 26: Defining success: a multicriteria approach to guide evaluation and investment," in Water for the Environment, eds A. C. Horne, J. Angus Webb, M. J. Stewardson, B. Richter, and M. Acreman (Cambridge, MA: Academic Press), 625-645. doi: 10.1016/B978-0-12-803907-6.00026-7

O'Donnell, E., and Talbot-Jones, J. (2017). Legal rights for rivers: what does this actually mean? Austr. Environ. Rev. 32, 159-162.

OECD (2015). OECD Principles on Water Governance: welcomed by Ministers at the OECD Ministerial Council Meeting on 4 June 2015. Online: Directorate for Public Governance and Territorial Development.

Olden, J. D., Konrad, C. P., Melis, T. S., Kennard, M. J., Freeman, M. C., Mims, M. C., et al. (2014). Are large-scale flow experiments informing the science and management of freshwater ecosystems? Front. Ecol. Environ. 12, 176-185. doi: $10.1890 / 130076$

Opperman, J., Hartmann, J., and Harrison, D. (2015). "Hydropower within the climate, energy and water nexus," in Climate, Energy and Water: Managing Trade-offs, Seizing Opportunities, eds J. Pittock, K. Hussey, and S. Dovers (Cambridge: Cambridge University Press), 79-107. doi: 10.1017/CBO9781139248792.006

Pahl-Wostl, C., Arthington, A., Bogardi, J., Bunn, S. E., Hoff, H., Lebel, L., et al. (2013). Environmental flows and water governance: managing sustainable water uses. Curr. Opin. Environ. Sustainability 5, 341-351. doi: 10.1016/j.cosust.2013.06.009

Pahl-Wostl, C., Sendzimir, J., Jeffrey, P., Aerts, J., Berkamp, G., and Cross, K. (2007). Managing change toward adaptive water management through social learning. Ecol. Soc. 12:30. doi: 10.5751/ES-02147-120230

Parsons, E. C. M., Favaro, B., Aguirre, A. A., Bauer, A. L., Blight, L. K., Cigliano, J. A., et al. (2014). Seventy-one important questions for the conservation of marine biodiversity. Conserv. Biol. 28, 1206-1214. doi: 10.1111/cobi. 12303

Poff, L. N., Brinson, M. M., and Day, J. W. J. (2002). Aquatic Ecosystems and Global Cliamte Change: Potential Impacts on Inland Freshwater and Coastal Wetland Ecosystems in the United States. Prepared for the Pew Center on Global Climate Change.

Poff, N. L. (2017). Beyond the natural flow regime? Broadening the hydroecological foundation to meet environmental flows challenges in a nonstationary world. Freshwater Biol. doi: 10.1111/fwb.13038. [Epub ahead of print].

Poff, N. L., Allan, J. D., Palmer, M. A., Hart, D. D., Richter, B. D., Arthington, A. H., et al. (2003). River flows and water wars: emerging science for environmental decision making. Front. Ecol. Environ. 1, 298-306. doi: 10.1890/ 1540-9295(2003)001[0298:RFAWWE]2.0.CO;2

Poff, N. L., Brown, C. M., Grantham, T. E., Matthews, J. H., Palmer, M. A., Spence, C. M., et al. (2016). Sustainable water management under future uncertainty with eco-engineering decision scaling. Nat. Clim. Change 6, 25-34. doi: $10.1038 /$ nclimate 2765

Poff, N. L., and Matthews, J. H. (2013). Environmental flows in the Anthropocence: past progress and future prospects. Curr. Opin. Environ. Sustainability 5 667-675. doi: 10.1016/j.cosust.2013.11.006

Poff, N. L., and Zimmerman, J. K. H. (2010). Ecological responses to altered flow regimes: a literature review to inform the science and management of environmental flows. Freshw. Biol. 55, 194-205. doi: 10.1111/j.1365-2427.2009.02272.x

Plurinational State of Bolivia (2010). Ley de Derechos de la Madre Tierra (Law of the Rights of Mother Earth). Law 071 of the Plurinational State.

Reidy Liermann, C. A., Olden, J. D., Beechie, T. J., Kennard, M. J., Skidmore, P. B., Konrad, C. P., et al. (2012). Hydrogeomorphic classification of Washington State rivers to support emerging environmental flow management strategies. River Res. Appl. 28, 1340-1358. doi: 10.1002/rra.1541

Richter, B. D., Davis, M. M., Apse, C., and Konrad, C. (2012). A PRESUMPTIVE STANDARD FOR ENVIRONMENTAL FLOW PROTECTION. River Res. Appl. 28, 1312-1321. doi: 10.1002/rra.1511

Rockström, J., Falkenmark, M., Allan, T., Folke, C., Gordon, L., Jägerskog, A., et al. (2014). The unfolding water drama in the Anthropocene: towards a resiliencebased perspective on water for global sustainability. Ecohydrology 7, 1249-1261. doi: $10.1002 /$ eco. 1562 
Rogers, K. H. (2006). The real river management challenge: integrating scientists, stakeholders and service agencies. River Res. Appl. 22, 269-280. doi: 10.1002/rra.910

Rolls, R. J., Leigh, C., and Sheldon, F. (2012). Mechanistic effects of low-flow hydrology on riverine ecosystems: ecological principles and consequences of alteration. Freshw. Sci. 31, 1163-1186. doi: 10.1899/12-002.1

Rudd, M. A., Beazley, K. F., Cooke, S. J., Fleishman, E., Lane, D. E., Mascia, M. B., et al. (2011). Generation of priority research questions to inform conservation policy and management at a national level generación de preguntas de investigación prioritarias para informar a las políticas y gestión de la conservación a nivel nacional. Conserv. Biol. 25, 476-484. doi: 10.1111/j.1523-1739.2010.01625.x

Schreiber, E. S. G., Bearlin, A. R., Nicol, S. J., and Todd, C. R. (2004). Adaptive management: a synthesis of current understanding and effective application. Ecol. Manage. Restor. 5, 177-182. doi: 10.1111/j.1442-8903.2004.00206.x

Seddon, A. W. R., Mackay, A. W., Baker, A. G., Birks, H. J. B., Breman, E., Buck, C. E., et al. (2014). Looking forward through the past: identification of 50 priority research questions in palaeoecology. J. Ecol. 102, 256-267.doi: 10.1111/1365-2745.12195

Smith, L., Porter, K., Hiscock, K., Porter, M. J., and Benson, D. (2015). Catchment and River Basin Management: Integrating Science and Governance. Oxon: Routledge.

Sutherland, W. J., Armstrong-Brown, S., Armsworth, P. R., Tom, B., Brickland, J., Campbell, C. D., et al. (2006). The identification of 100 ecological questions of high policy relevance in the UK. J. Appl. Ecol. 43, 617-627. doi: $10.1111 /$ j.1365-2664.2006.01188.x

Sutherland, W. J., Freckleton, R. P., Godfray, H. C. J., Beissinger, S. R., Benton, T., Cameron, D. D., et al. (2013). Identification of 100 fundamental ecological questions. J. Ecol. 101, 58-67. doi: 10.1111/1365-2745.12025

Tan, P.-L., and Auty, K. (2017). "Finding Diamonds in the Dust - Community Engagement in Murray-Darling Basin Planning," in Decision-Making in Water Resources Policy, Planning and Management: The Australian Experience, eds B. T. Hart and J. Doolan (Boston, MA: Elsevier Publishing), 183-202.

Tan, P.-L., and Jackson, S. (2013). Impossible dreaming - does Australia's water law and policy fulfil indigenous aspirations? Environ. Plan. Law J. 30, 132-149.

Thomas, G. A. (2017). "Chapter 21: Managing infrastructure to maintain natural functions in developed rivers," in Water for the Environment, eds A. C. Horne, J. Angus Webb, M. J. Stewardson, B. Richter, and M. Acreman (Cambridge, MA: Academic Press), 483-518. doi: 10.1016/B978-0-12-803907-6.00021-8

Tickner, D., and Acreman, M. (2013). "Water security for ecosystems, ecosystems for water security," in Water Security: Principles, Perspectives, and Practices, Earthscan Water Text Series, eds B. Lankford, K. Bakker, M. Zeitoun, and D. Conway (Abingdon: Routledge), 130-147.

Tickner, D., Parker, H., Moncrieff, C. R., Oates, N. E. M., Ludi, E., and Acreman, M. (2017). Managing rivers for multiple benefits-a coherent approach to research, policy and planning. Front. Environ. Sci. 5:4. doi: 10.3389/fenvs.2017.00004 von Korff, Y., Daniell, K. A., Moellenkamp, S., Bots, P., and Bijlsma, R. M. (2012). Implementing participatory water management: recent advances in theory, practice, and evaluation. Ecol. Soc. 17:30. doi: 10.5751/ES-04733-170130

Webb, J. A., Koster, W. M., Stuart, I. G., Reich, P., and Stewardson, M. J. (2016). "Adaptive management of Australian grayling recruitment: using Bayesian models and indicator species to assess benefits of spring flows," in Proceedings of the 11th International Symposium on Ecohydraulics, eds J. A. Webb, J. F. Costelloe, R. Casas-Mulet, J. P. Lyon, and M. J. Stewardson (Melbourne, VIC: The University of Melbourne).

Webb, J. A., Miller, K. A., King, E. L., de Little, S. C., Stewardson, M. J., Zimmerman, J. K. H., et al. (2013). Squeezing the most out of existing literature: a systematic re-analysis of published evidence on ecological responses to altered flows. Freshw. Biol. 58, 2439-2451. doi: 10.1111/fwb. 12234

Webb, J. A., Watts, R. J., Allan, C. A., and Warner, A. (2017). "Chapter 25: Principles for monitoring, evaluation, and adaptive management of environmental water regimes," in Water for the Environment, eds A. C. Horne, J. Angus Webb, M. J. Stewardson, B. Richter, and M. Acreman (Cambridge, MA: Academic Press), 599-623. doi: 10.1016/B978-0-12-803907-6.00025-5

Westgate, M. J., Likens, G. E., and Lindenmayer, D. B. (2013). Adaptive management of biological systems: a review. Biol. Conserv. 158, 128-139. doi: $10.1016 /$ j.biocon.2012.08.016

Williams, B. K., and Brown, E. D. (2014). Adaptive management: from more talk to real action. Environ. Manage. 53, 465-479. doi: 10.1007/s00267-013-0205-7

Winemiller, K. O., McIntyre, P. B., Castello, L., Fluet-Chouinard, E., Giarrizzo, T., Nam, S., et al. (2016). Balancing hydropower and biodiversity in the Amazon, Congo, and Mekong. Science 351, 128-129. doi: 10.1126/science. aac7082

Yarnell, S. M., Petts, G. E., Schmidt, J. C., Whipple, A. A., Beller, E. E., Dahm, C. N., et al. (2015). Functional flows in modified riverscapes: hydrographs, habitats and opportunities. Bioscience 65, 963-972. doi: 10.1093/biosci/biv102

Zarfl, C., Lumsdon, A. E., Berlekamp, J., Tydecks, L., and Tockner, K. (2015). A global boom in hydropower dam construction. Aquat. Sci. 77, 161-170. doi: 10.1007/s00027-014-0377-0

Conflict of Interest Statement: The authors declare that the research was conducted in the absence of any commercial or financial relationships that could be construed as a potential conflict of interest.

Copyright (c) 2017 Horne, Webb, O'Donnell, Arthington, McClain, Bond, Acreman, Hart, Stewardson, Richter and Poff. This is an open-access article distributed under the terms of the Creative Commons Attribution License (CC BY). The use, distribution or reproduction in other forums is permitted, provided the original author(s) or licensor are credited and that the original publication in this journal is cited, in accordance with accepted academic practice. No use, distribution or reproduction is permitted which does not comply with these terms. 